\title{
Inactivating ATM Gene Mutation
}

National Cancer Institute

\section{Source}

National Cancer Institute. Inactivating ATM Gene Mutation. NCI Thesaurus. Code

C162040.

A change in the nucleotide sequence of the ATM gene that either inhibits expression of the serine-protein kinase ATM protein or results in the translation of an inactive serineprotein kinase ATM protein. 